\title{
The Lived Experience of Physical-Motor Disability Due to Traffic Accidents: A Phenomenological Study
}

\begin{abstract}
Background and Objective: A significant proportion of spinal cord injuries and physical-motor disabilities are caused by road traffic crashes. The aim of this study was to explore the lived experiences of people with disability due to traffic accidents. Materials and Methods: This study was conducted using a qualitative phenomenological approach. The participants were a purposive sample of physical-motor disabled people due to road traffic injuries referred to the rehabilitation centers in East Azerbaijan, Iran. Data were collected using individual in-depth interviews and analyzed with a thematic analysis including holistic, selective and detailed approaches. Results: The main theme extracted from the experience of the participants was "captive of destiny" with three sub-themes including 'surrender of fate', 'living behind the fence' and 'drowning in disability and need'. Accordingly, participants considered themselves as the victims of destiny and believed living with disability is like living behind the fences of loneliness, frustration, regret, fear of future, pity and inefficiency.

Conclusion: This study revealed that spinal cord disability imposed irreversible restrictions on the participants' lives, so that as dependent people, they needed support from others and, were desperate to recover their lost power, found them in the fate prison. Social support and empowerment of these people to overcome disability can improve their mental health and help them return to a normal life. Keywords: Physical-motor disability, spinal cord injury, road traffic injuries. Paper Type: Research Article.
\end{abstract}

Citation (Vancouver): Hashemiparast M, Sheydaei H, Gharacheh M. The Lived Experience of Physical-Motor Disability Due to Traffic Accidents: A Phenomenological Study. Iran J Health Educ Health Promot. Spring 2021;9(1): 20-32. [Persian]

- Citation (APA): Hashemiparast M., Sheydaei H., Gharacheh M. The Lived Experience of Physical-Motor Disability Due to Traffic Accidents: A Phenomenological Study. Iranian Journal of Health Education \& Health Promotion., 9(1), 20-32 . [Persian]

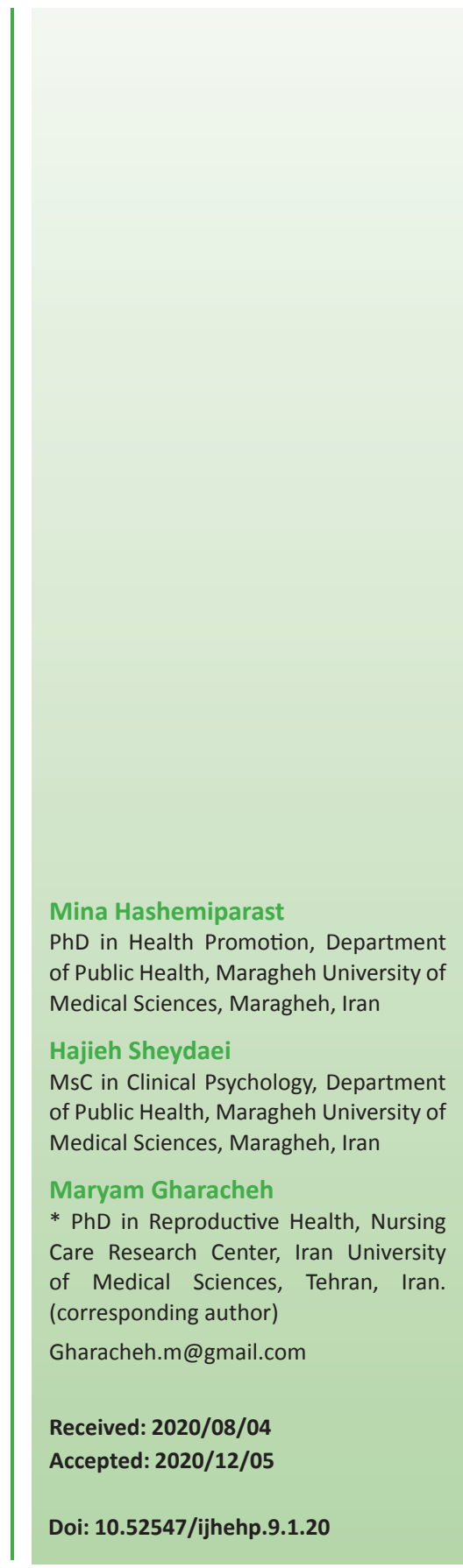




\section{تبيين تجربه زندكى با معلوليت جسمى-حركتي ناشى از تصادفات ترافيكى:}

يك مطالعه بديدارشناسىى

مينا هاشمى برست دكتراى آموزش بهداشت و ارتقاء سلامت، استاديار،

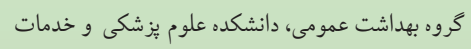
بهداشتى درمانى مراغه، مر اغه، ايران حاجيه شيدايى كارشناس ارشد روانشناسى بالينى، مربى، دانشكده علوم يزشكى و خدمات بهداشتى درمانى مراغه، مراغه، ايران دران مريم قراحه

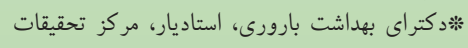

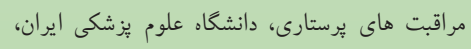
Gharacheh.m@gmail.com

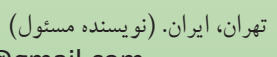

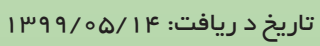

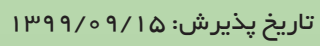

\section{ن بخ و}

زمينه و هدف : بخش عمدهاى از آسيب هاى نخاعى و معلوليت هاى جسمى -حر كتى، ناشى از سوانح ترافيكى

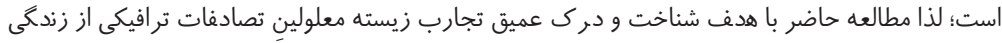
با معلوليت انجام شده است.

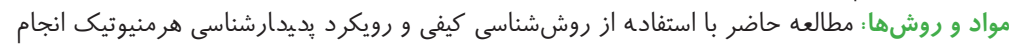

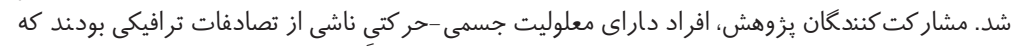

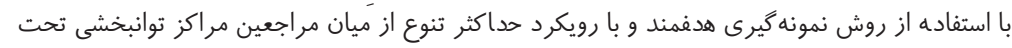

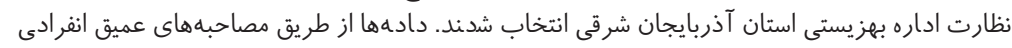

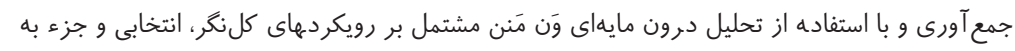

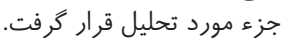

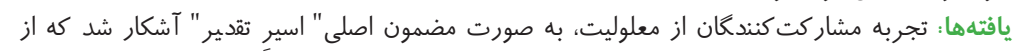

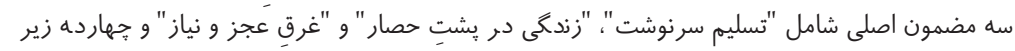

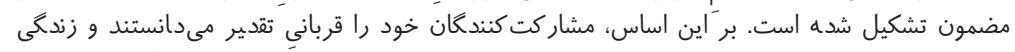

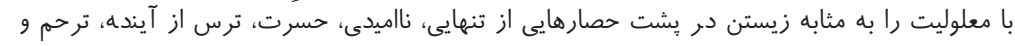

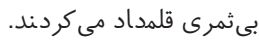

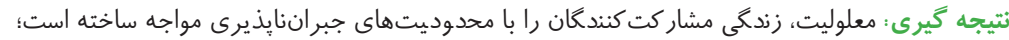

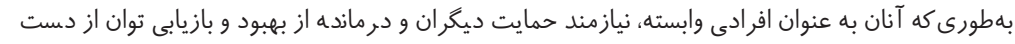

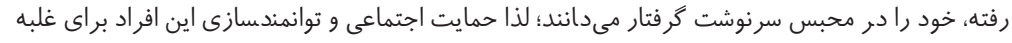

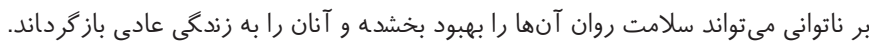

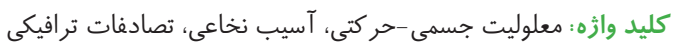
نوع مقاله : مطالعه يروهشى.

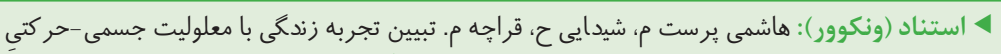

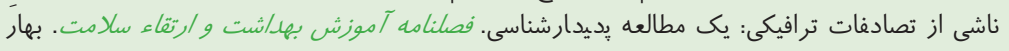

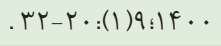

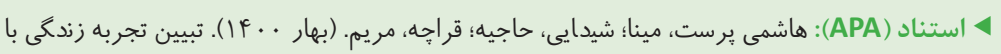

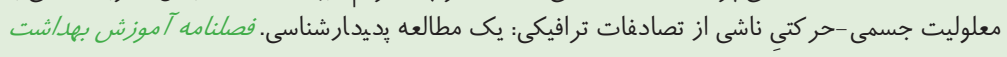

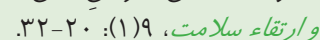


معلوليت و صدمات ناشى از تصادفات ترافيكى علاوه بر اين كه كيفيت زندكى مصدومين و اعضاى خانو اده آنها را تحت تاثير قرار مىدهد، به عنوان مانعى مهم در رشد و توسعه اجتماعى و اقتصادى كشور قلمداد مىشود (11). از سوى ديخر، معلولين ناشى از سوانح ترافيكى محدوديتهاى كوناگونى رادر حوزههاى مختلف جسمانى، عملكرد اجتماعى، سلامت

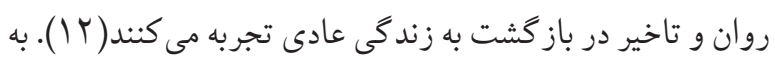

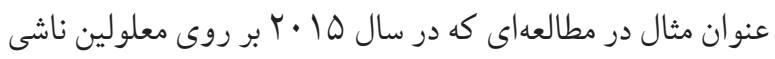
از تصادفات ترافيكى در اسيانيا انجام شد مشخص شد كه معلوليت

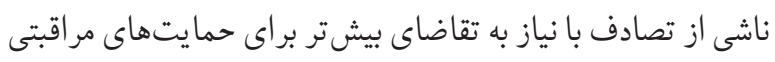

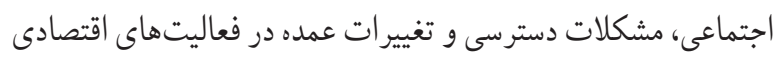
آنان همراه است (1) - (1). علاوه بر اين، با توجه به اين كه معلوليت ناشى از تصادفات

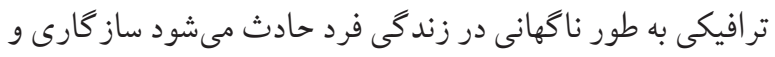

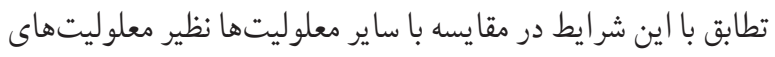
مادرزادى و يا ضايعات نخاعى ناشى از جنگ تحميلى دشوارتر است. اين موقعيت براى معلولين در جامعه ايرانى بيجيدهتر است؛

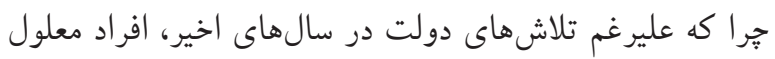
همجنان دسترسى ضعيفى به سيستم حمل و نقل و مبلمان شهرى

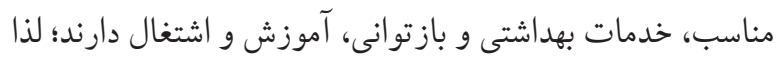

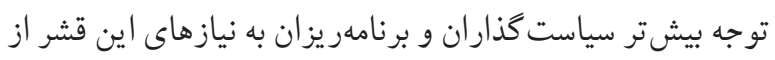
اعضاى جامعه ضرورت دارد (I ( I). عليرغم جالشهاى موجود، اطلاعات اندكى در زمينه تجربه زندكى إلى با معلوليت در سراسر جهان وجود دارد. بررسى هاى صورت گرفته در درد

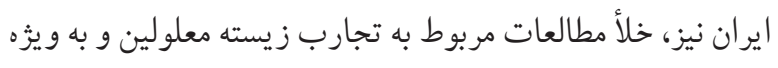

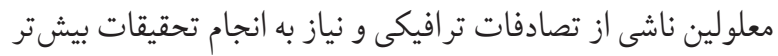

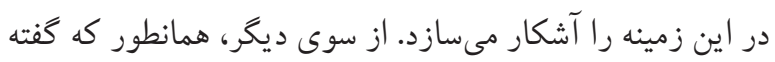

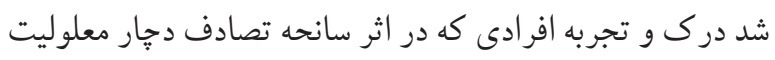

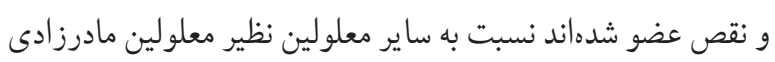

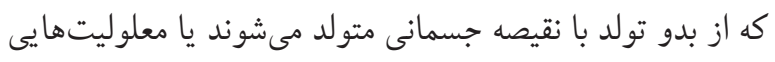

معلوليت به عنوان קديدهاى جهانى، وضعيتى است كه در آن انجام

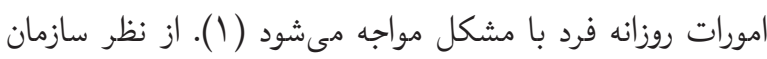

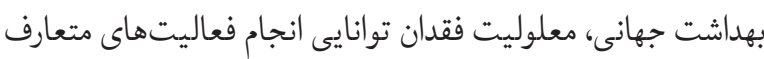

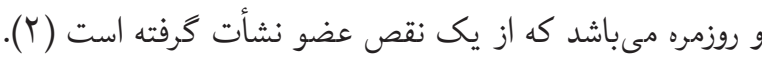
يكى از شايع ترين انواع معلوليتها، معلوليتهاى ناشى از آسيبها

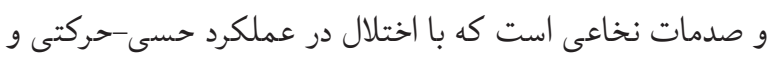
محدوديتهاى فيزيكى همراه است (ץ). صدمات نخاعى به دلايل غير تروماتيك و تروماتيك نظير تصادفات ترافيكى، سقوط و همران ورزشهاى مختلف رخ مىدهد كه از اين ميان، تصادفات ترافيكى

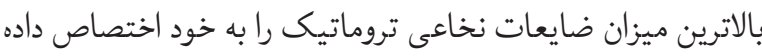

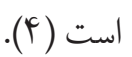

براساس كزارشات سازمان بهداشت جهانى، سالانه بيش از دهها

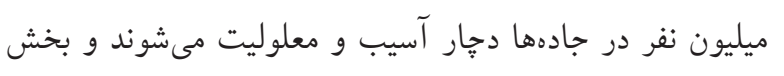
معنى دارى از معلوليتها در جهان توسط تصادفات ترافيكى ايجاد

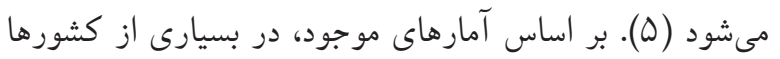

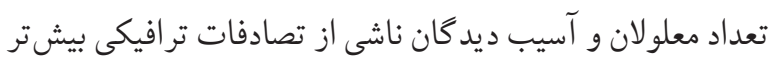
از تعداد كشته شدكان ناشى از اين سانحه است؛ بهطورى كه تصادفات ترافيكى، سومين دليل منجر به بروز معلوليت در سراسر جهان بوده و

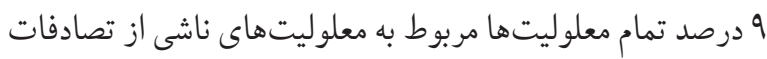

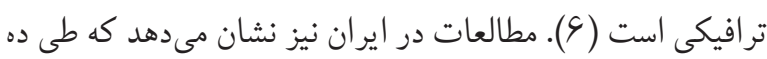

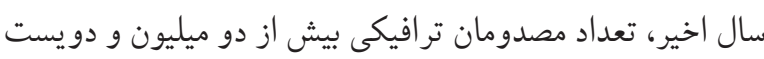

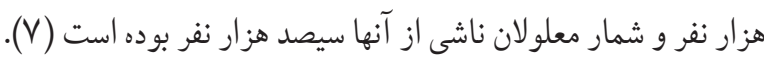

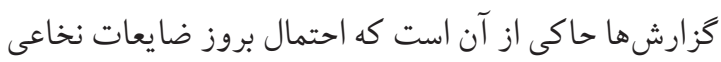

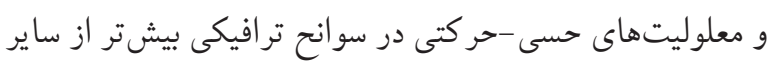

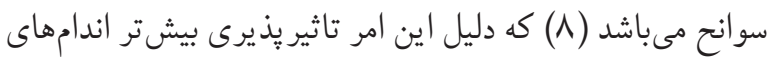

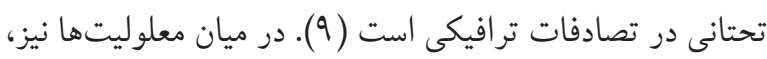

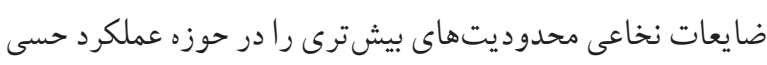

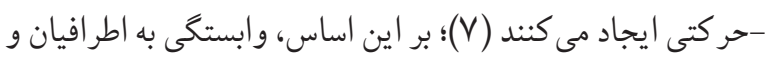

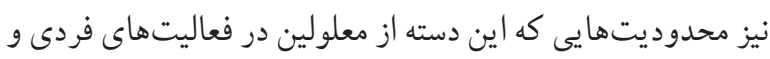
اجتماعىشان تجربه مى كنند بيشتر از ساير معلوليتهاست ( • (1). 
تنوع در ويثگى هايى نظير سن، جنسيت و طول مدت معلوليت فرد ياسخكو انجام شد.

دادها با استفاده از مصاحبهاى عميق انفرادى جمع آورى شدند. مصاحبه كننده يّ از حضور در عرصه و معرفى خود، در اتاقى بـى

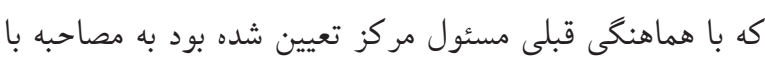

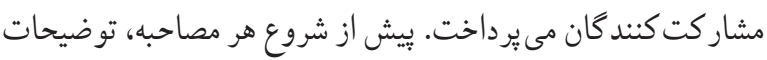
لازم در خصوص هدف يزوهش داده مىشد و با تأكيد بر محرمانه

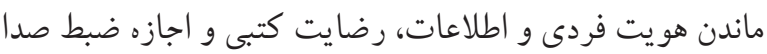

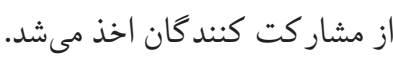

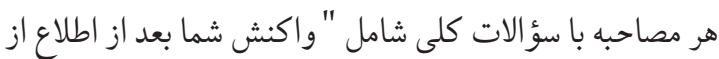

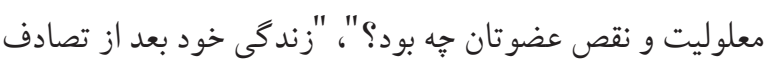

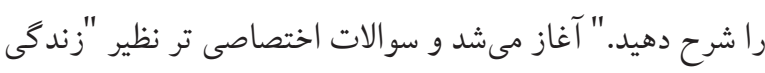

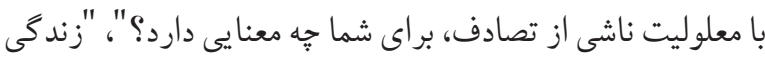

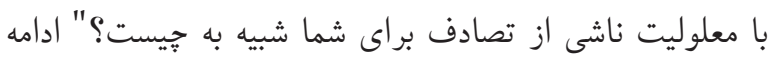
مى يافت. سؤ الات ديخر متناسب با صحبت هاى مشار كت كنند كان و نيز سؤالات عمقدهنده و اكتشافى نظير: لطفا در اين مورد بيشتر

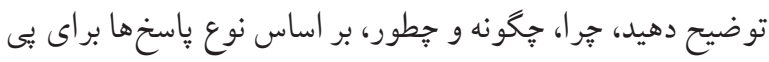
بردن به عمق تجربيات مصاحبهشوند كان مطرح مىشد.

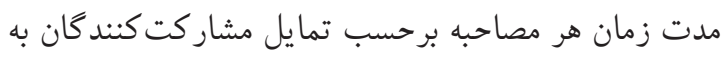

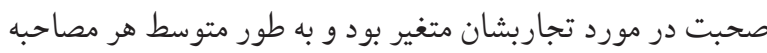
بين · F تا · P دقيقه طول كشيد. هر مصاحبه با كسب اجازه از مشاركت كنند كان، ضبط و سيس كلمه به كلمه بياده شد. مصاحبهها بهور همزمان با تحليل انجام مى شد، بهطورى كه هر مصاحبه، جهت

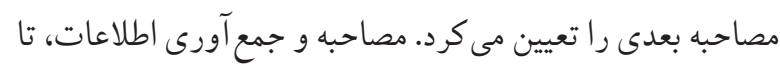
زمان رسيدن به غناى دادهها ادامه يافت.

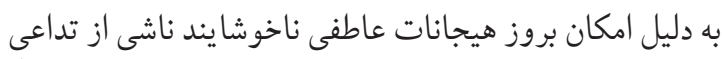

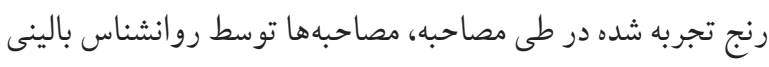

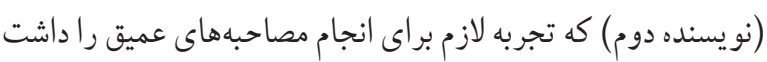
انجام مىشد و در صورت نياز، به حمايت روانى و ارائه راهكار

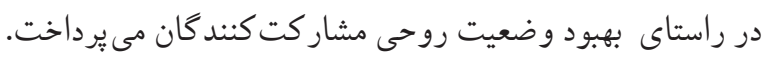

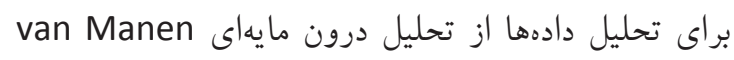

كه در اثر حوادث شغلى ايجاد شده و نيز جانبازان داراى ضايعات نخاعى ناشى از جنگ تحميلى متفاوت باشد؛ لذا شناخت اين بديده

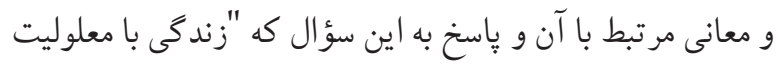

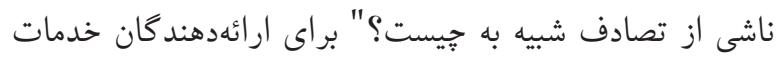
سلامت ضرورى است. مطالعه حاضر در صدد است تا با شناخت و درى عميق تجارب زندگى شده معلولين ناشى از تصادفات ترافيكى از زندكى با معلوليت

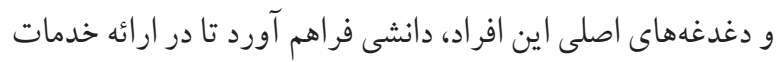

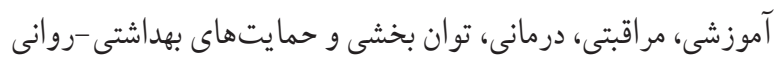

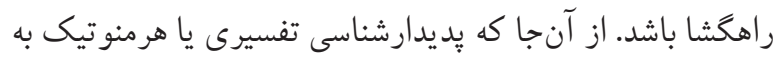

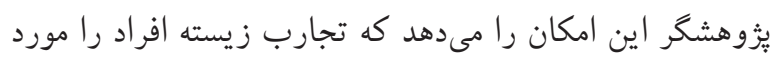
كاوش عميق قرار داده و در بستر فرهنكى و اجتماعى خاص آن تفسير نمايد، پايه هاى فلسفى تحقيق حاضر بر بايه اين داين رويكرد

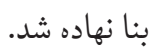
روش برورسى

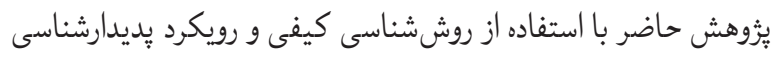

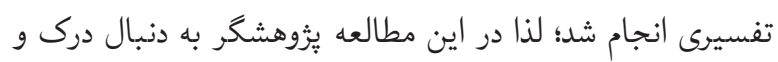
تفسير تجارب مشاركت كنندگان از زندگى با معلوليتِ ناشى از تصادف، جوهره و معناى قرار گرفته در تجربه معلوليت بود.

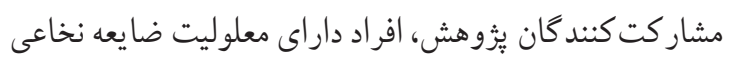
ناشى از تصادفات ترافيكى بودند كه در اثر سانحه تصادف دجار آسيب و عارضه دائمى شده بودند. اين افر اد از ميان مراجعين مر اكز توانبخشى تحت نظارت اداره بهزيستى استان آذربايجان شرقى انتخاب شدند؛ بدين ترتيب كه پس از مشخص كردن افر اد داراى

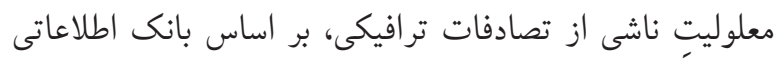

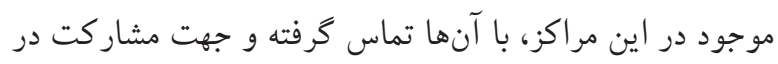

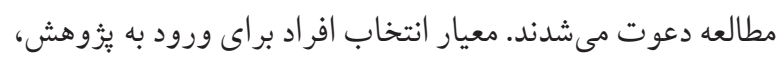
داشتن معلوليت حركتى بود كه در نتيجه تصادف حادث شده بود؛

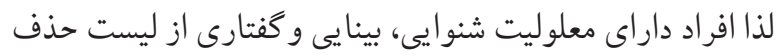

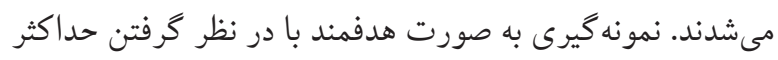


يافتنه ها

به منظور دستيابى به تجربه زيسته مشاركت كنندگان از زندكى با

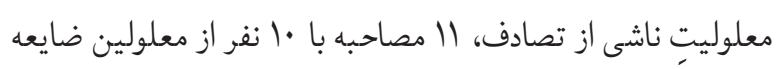
نخاعى انجام شد كه جزئيات مربوط به مشخصات مشاركت كنندگان در جدول شماره آ آمده است.

جدول ا: مشخصات دمو ََرافيك مشاركت كند كَان در يُوهش

\begin{tabular}{|c|c|c|c|c|}
\hline معلوليت (سال) & وضأهل & سن (سال) & جنسيت & شندار كتان \\
\hline IV & مجرد & rI & مرد & 1 \\
\hline 4 & مجرد & $\mu_{1}$ & زن & $r$ \\
\hline V & مجرد & $r F$ & مرد & $r$ \\
\hline$r v$ & متأهل & $s q$ & مرد & r \\
\hline$r$ & متأهل & rr & زن & $\Delta$ \\
\hline IV & متأهل & er & مرد & 4 \\
\hline$\wedge$ & متأهل & $\Delta \Delta$ & مرد & v \\
\hline (ماه) & مجرد & $r$. & زن & $\wedge$ \\
\hline r & مجرد & r & زن & 9 \\
\hline$r$ & مجرد & iᄉ & زن & 1. \\
\hline
\end{tabular}

در يُزوهش حاضر، "اسير تقدير" مضمون اصلى استخراج شده از

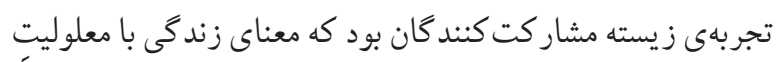

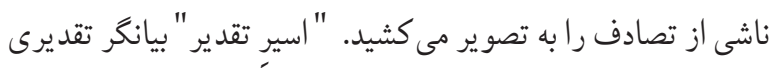

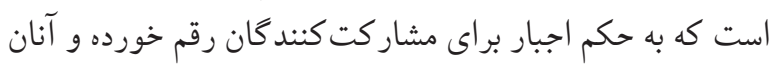

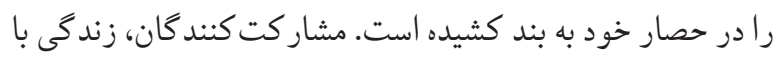
معلوليت را حاصل تقدير و سرنوشتى مى دانستند كه به حكم اجبار

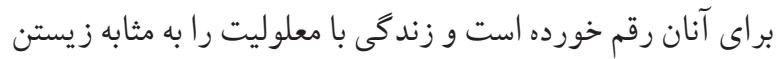

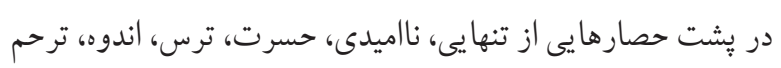

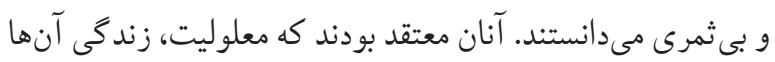

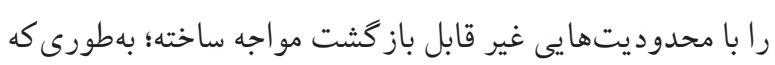

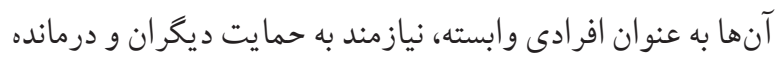

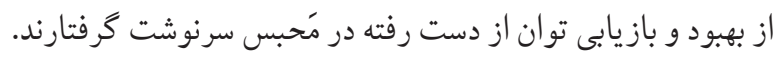

كه مشتمل بر رويكردهاى كلنگر، انتخابى و جزء به جزء است

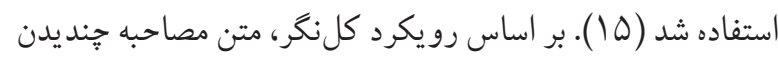

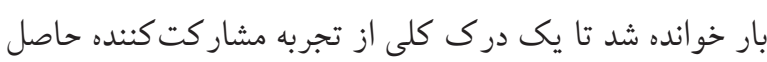

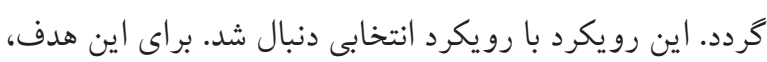
محقق متن مصاحبه را جندين بار مى خواند و عبارت هايى از سخنان

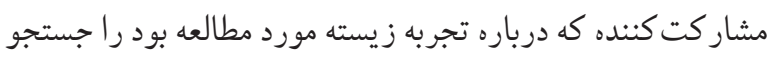

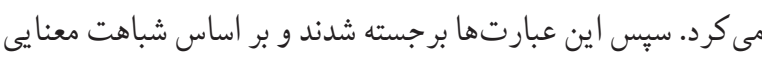

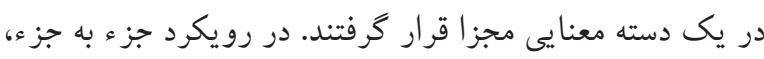

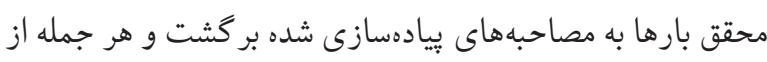

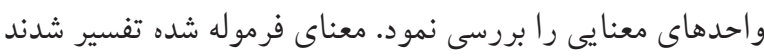

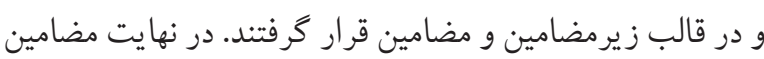

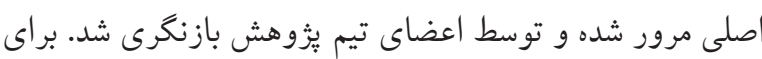

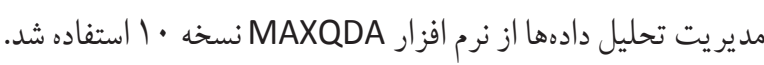

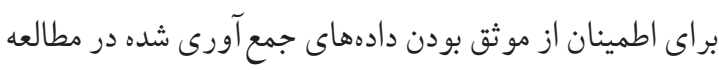
حاضر، جهار معيار اعتبار، قابليت اطمينان، قابليت تأييد و قابليت انتقال معرفى شده توسط كوبا و لينكلن استفاده شد (19).

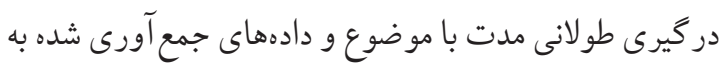
محقق اصلى كمى كرد تادرى بهترى از يديدهى مورد مطالعه حاصل

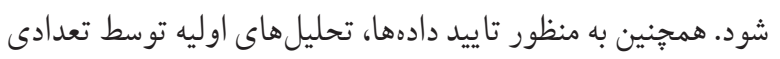

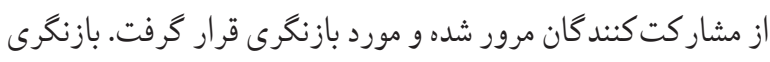

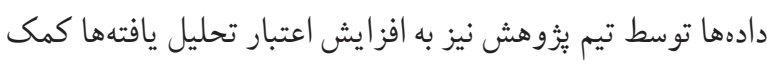
كرد. محققان تلاش نمودند، زمينه و مشخصات مشار كت كنند كان و نيز مسير تحقيق را بهروشنى و بهطور كامل بيان كنند تا محققينى كه قصد دارند مسير تحقيق رادنبال كنند از آن استفاده نمايند. اخلاق يُزوهش از طريق بيان اهداف و اطمينان دادن به ديه

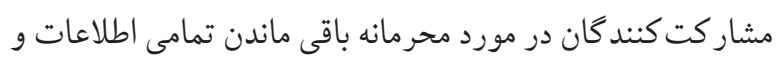
صداهاى ضبط شده، كسب رضايت آكاهانه كتبى براى مشار كت در مر ماند يُّوهش، حفظ بى نامى و توضيح حق كناره گيرى مشار كت كنند

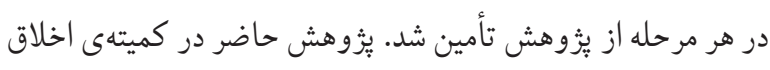

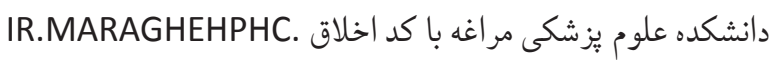
REC.1397.007 به تصويب رسيده است. 


.

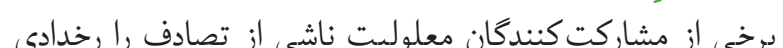

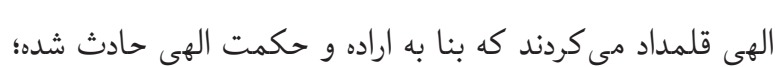
بهطورى كه راهى جز تسليم شدن در برابر مشيت الهى برايشان

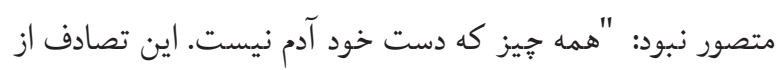

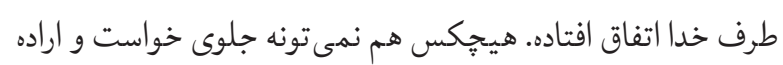
خدارو بكيره. يس خارهاى جز تسليم شدن ندارم". (مشاركت كننده V) ا, س. سوختن در كوره امتحان الهى

برخى از مشاركت كنندگان معلوليت را نتيجه امتحان الهى مى دانستند؛

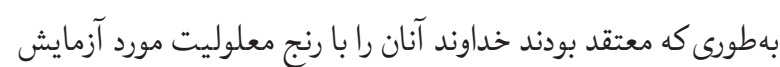

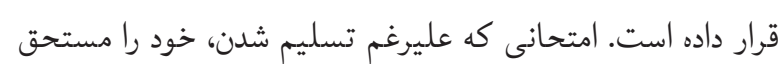

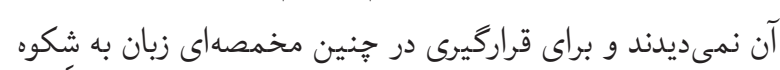

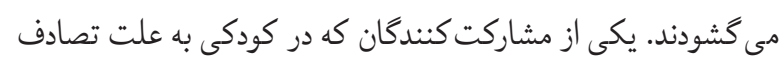

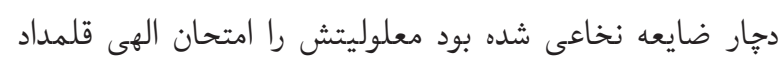
مى كرد، مى گفت: "... خدا نبايد با من اينكارو ميكرد. من بجهه بودم و گناهى نداشتم، حقم نبود. اصلا جرا بايد خدا منو امتحان

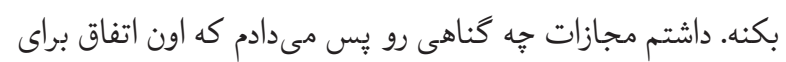

$$
\begin{aligned}
& \text { من افتاد". (مشاركت كننده ا ) } \\
& \text { r. زندگى در خشت حصار }
\end{aligned}
$$

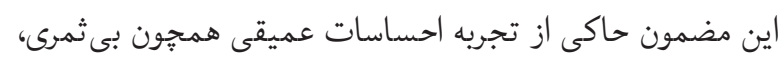

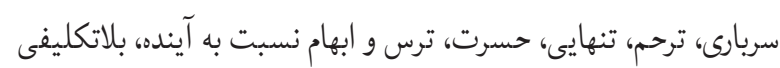

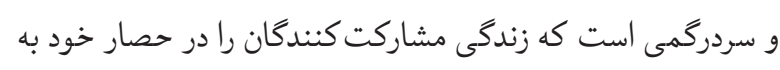
بند كشيده است و شامل هفت زير مضمون به شرح ذيل مى مباشدي

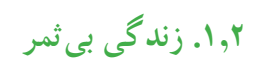

اين زير مضمون بيانكر احساس ناخوشايند ناكارآمدى و مفيد نبودن تُنر

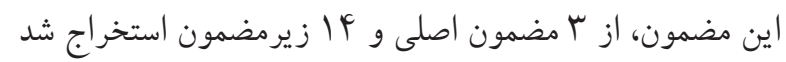

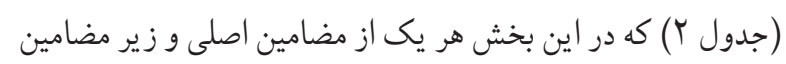
مربوط به آنها به تفصيل شرح داده شده است. جدول r: خلاصه مضامين اصلى و زير مضامين

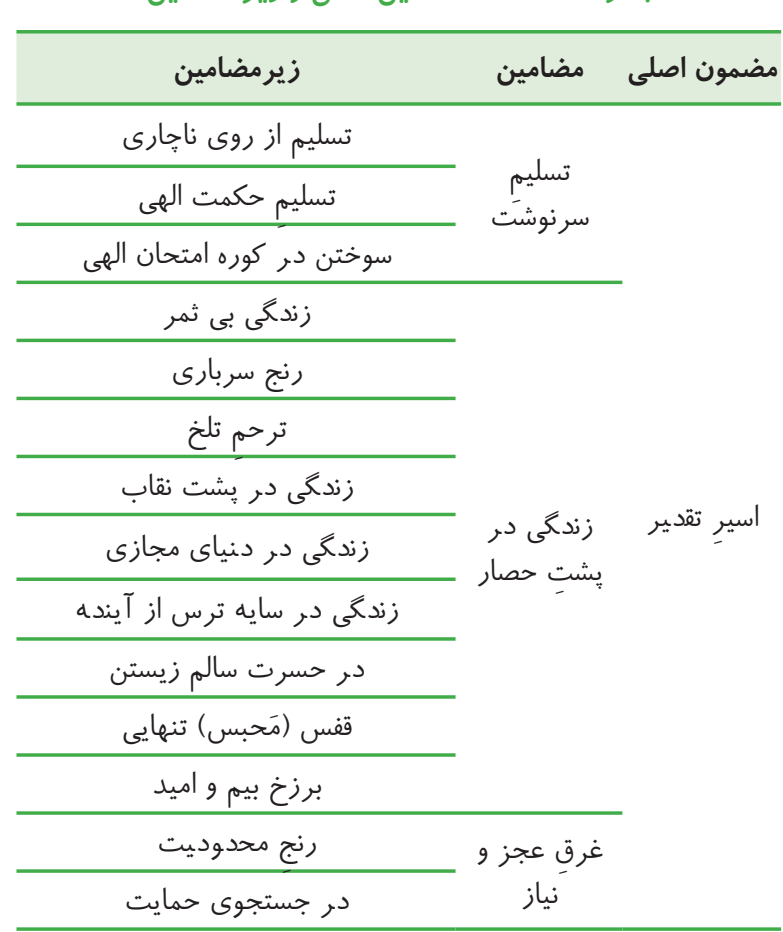

$$
\text { ا.تسليم سرنوشت }
$$

"تسليم سرنوشت" يكى از مضامين اصلى استخراج شده از تجربه

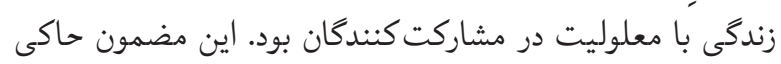
از سرنوشتى است كه بنا به تقدير الهى و خارج از اراده و اختيار

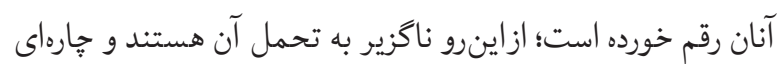
جز تسليم شدن ندارند. تسليم سرنوشت شامل زيرمضامين تسليم

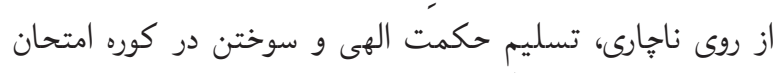

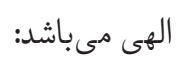
1, إ. تسليم از روى ناجارى مشاركت كنندگان معتقد بودند كه معلوليتِ ناشى از تصادف، تقدير

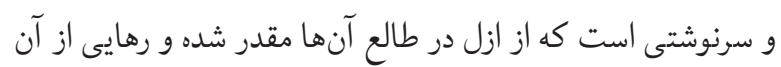

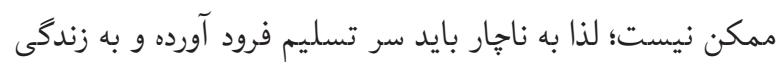

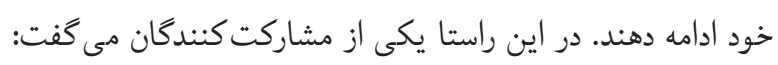

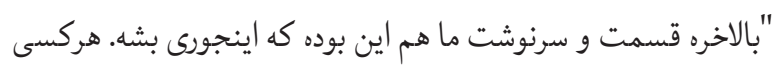




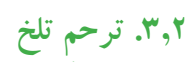
يكى ديكر از تجارب ناخوشايندى كه مشاركت كنندكان در بيانات خود به آن اشاره كردند، توجه بيجا و بيش از از حد ديكران بود كه كه آن آن را به منزله ترحم و توهين تلقى ميى كردند. ناراحتى از ترحم ديكران،

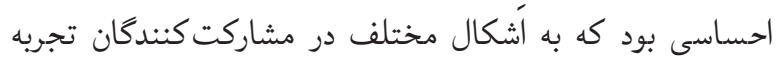

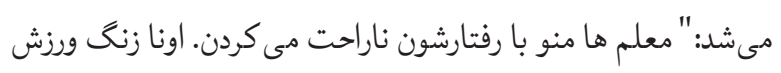

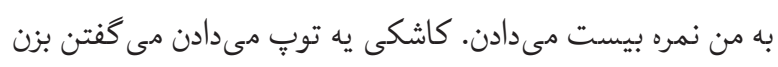

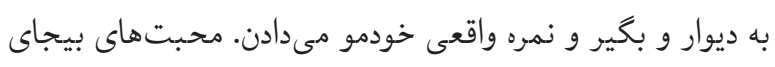
بعضيا براى آدم توهين تلقى ميشه ". (مشاركت كننده ا). "...

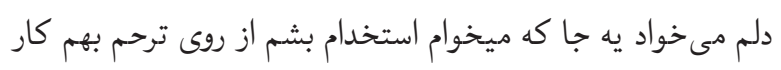

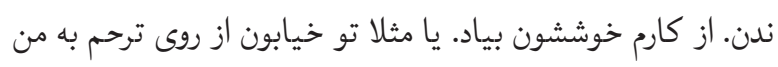

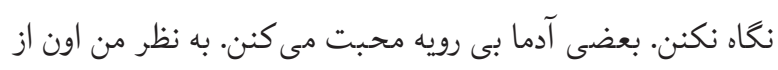

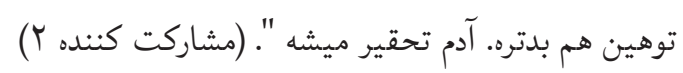

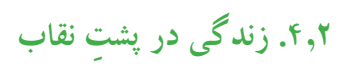

اين زيرمضمون به ينهان كردن احساسات واقعى و اندوه درونى از

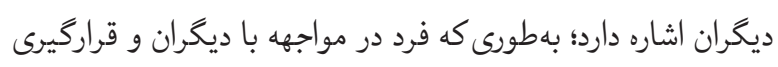

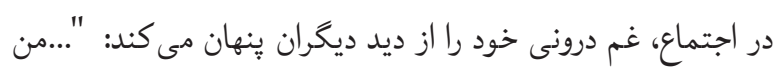
سعى مى كنم بخم بخندم غم هامو به هيج كس نخم. سعى مى كنم

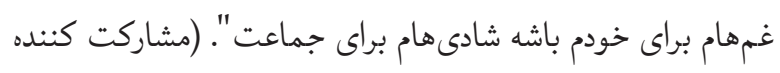

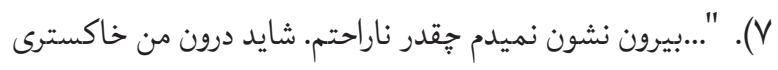
باشه ولى ميخوام اطرافيانم اين دنيارو رنكى ببينن". (مشاركت كننده 9). برخى از مشاركت كنندگان به ناجار احساسات واقعى و و

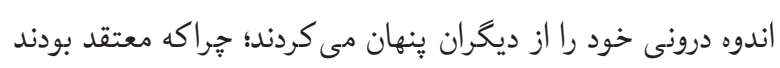

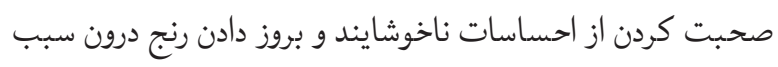
خسته شدن اطرافيان و در نهايت منجر به انزواى آنان خواهد شد:

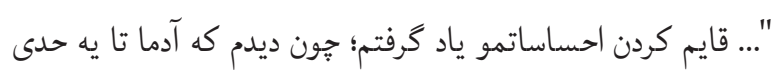
تحمل دارن، بيش از حد كه بشه نمى تونن تحمل كنن. نمى خوام برن پشت سرم بحن رفتيم بيش فلانى همش كريه و ناله كرد ".

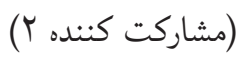

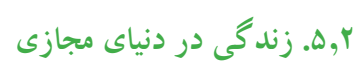
برخى از مشاركت كنندكان به دليل محدوديتهاى جسئ درى دمانى ناشى
است كه بر تمام ابعاد و جنبههاى زندكى مشاركت كنندكان سايه افكنده است. بر اساس بيانات مشاركت كنندكان، وابستكى به ديخران

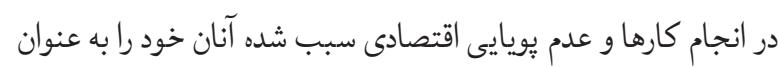
موجودى بى ارزش تلقى كنند؛ بهطورى كه برخى از مشاركت كنندگان

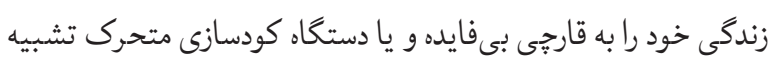

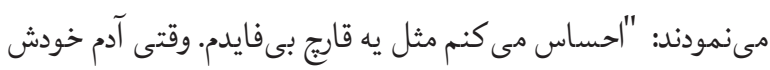
يه ليوان آب نمى تونه براى خودش بياره اين زندكى اصلا ارزشى نداره".

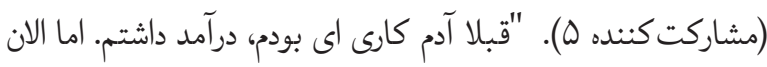

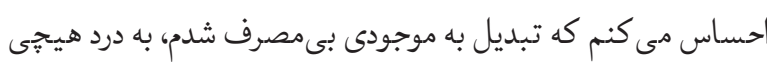

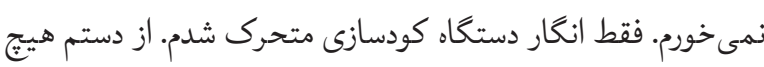
كارى برنمياد". (مشاركت كننده V) . يككى از مشاركت كنندكان كه در رسيدكى به فرزند خردسال خود احساس عجز و ناتوانى مى كرد و معتقد بود كه قادر به انجام وظايف مادرى براى كودكش نيست، ورنس

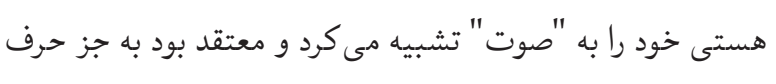

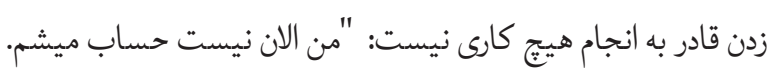

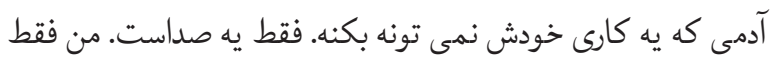
يه صدام". (مشاركت كننده ه)

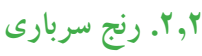

يكى ديكر از احساسات تلخى كه مشاركت كنندكان با آن دست و ينجه

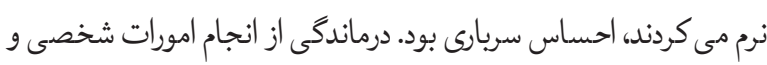
وابستكى هميشخى به ديخران به دليل ناتوانى ناشى از معلوليت، آنان

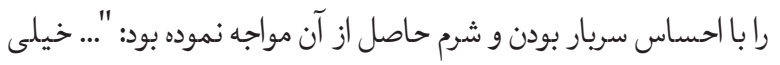
سخته كه هميشه يه آدم بايد كنارم باشه. آدم زندكى خودشم بهم مي خوره زندكى اطرافيانشم بهم مى خوره. جند نفر ديكه رو هم اسير خودم كردم. كاش مى مردم و اينطورى سريار ديخران نمى شدم ". (مشاركت كننده ه).

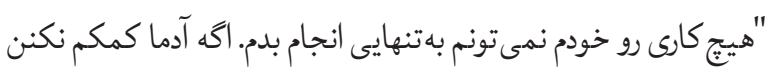

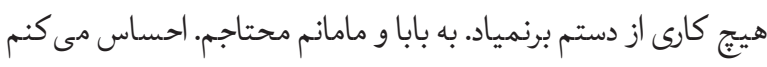

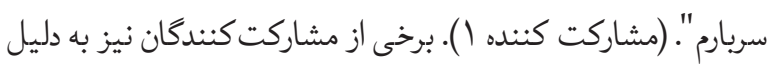

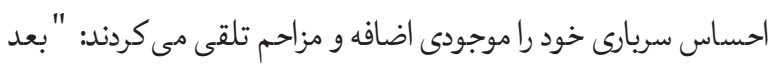
از تصادف زندكيم خيلى سرد شده. احساس مى كنم اضافهام. مزاحمم.

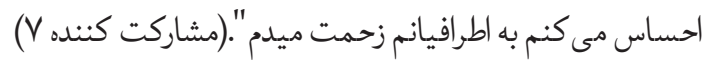


خواهرامو مىديدم كه از نظر قيافه از من پايين تر بودن و وقتى خودمو از اينا عقب مىديدم نمى تونستم راه برم، ناراحت مي شدم

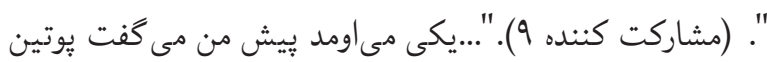
خريدم من نمى تونستم تحمل كنم. گذشته خودم به يادم مى اومد

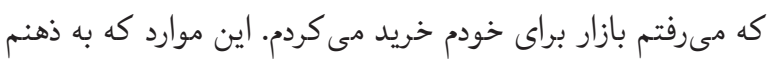
مىاومد نمى تونم توصيف كنم كه به جه حالى مى بـ افتادم. كريه

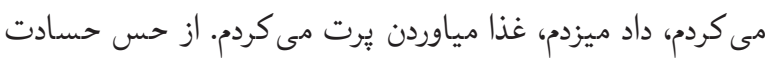

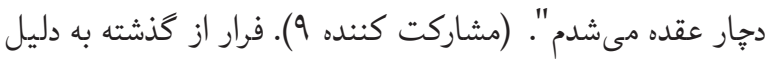

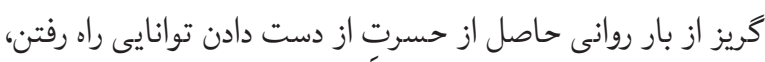
تجربه ديكرى بود كه مشاركت كنندگان در بيانات خود به آن اشاره

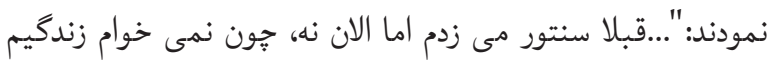

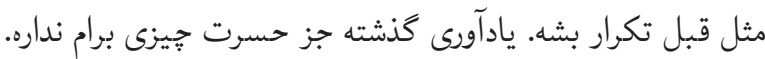

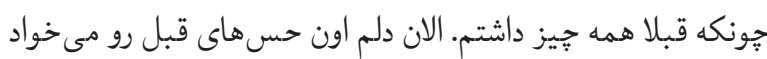

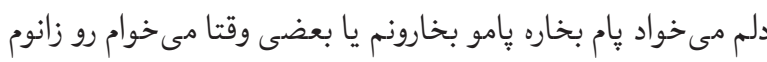

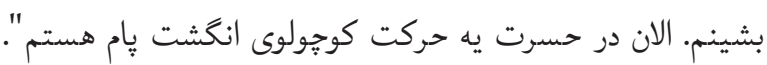

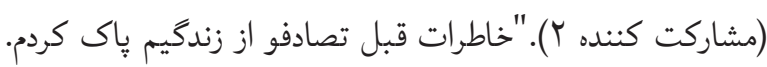
انغار تو زندكيم اصلا وجود نداشته. جون الان گردش هايى كه رفتم وقتى يادم مى افته عجيب حالم بد ميشه و حسرتشو مى خورم".

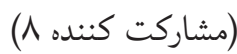

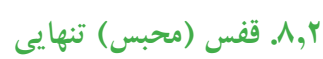
اين زيرمضمون بيانكر احساس عميق تنهايى است كه زندكى مشاركت كنندكان را در حصار خود به بند كشيده است. مشاركت كنندكان

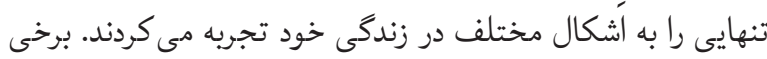

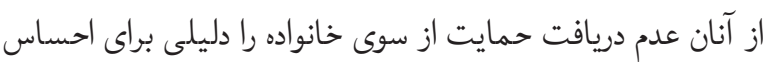

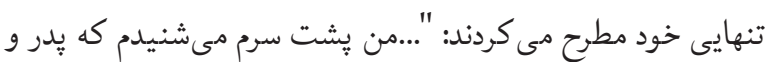
مادرم مى گفتن ما نمى تونيم نخهش داريم بايد اينو بديم به بهزيستى.

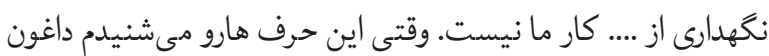
مى شدم. يعنى به نوعى خانواده داشت منو طرد مى كرد و من فهميدم كه تنهام". (مشاركت كننده 9) . بى توجهى و و ناديده كرفته شدن از از

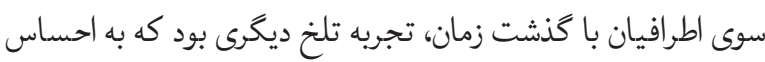

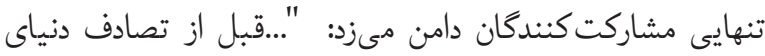

از معلوليت، از طريق تصويرسازى ذهنى و خيال يردازى، خود را در حال انجام فعاليتهاى مورد علاقهان تصور مىكردند و معتقد بودند كه جون در دنياى حقيقى قادر به انجام اين فعاليتها نيستند،

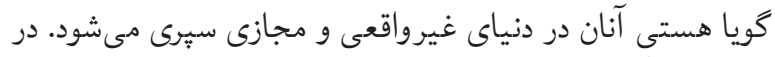

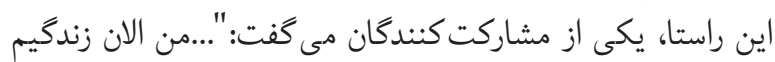

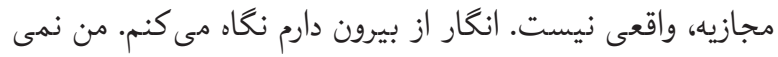
تونم كوه برم، تفيح كنم. فقط تماشا مى كنم و تصور مى كنم خودم

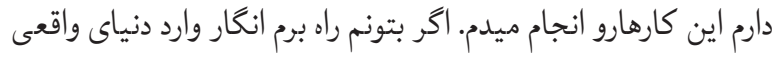
ميشم". (مشاركت كننده l)

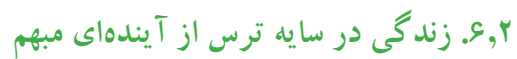
يكى از زيرمضامينى كه از تجارب تمامى مشاركت كنندكان ادراك شد،

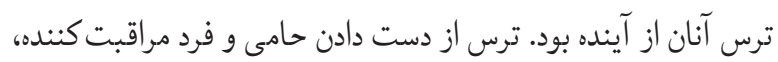

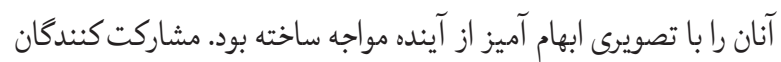

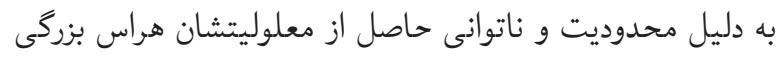

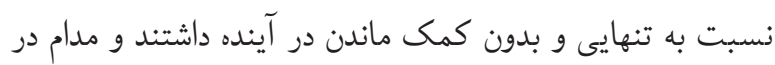

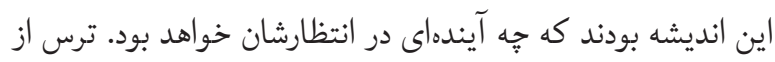
آينده، در بيانات برخى از مشاركت كنندگان قابل استحصال است:"

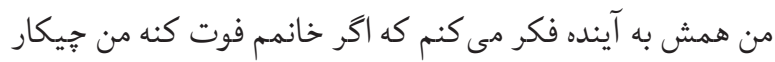

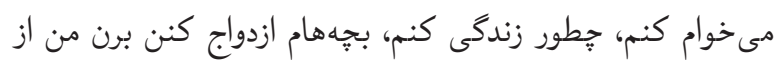
دست و پا بيفتم جيكار مى خوام بكنم". (مشاركت كننده ^). "... بزركترين ترسم اينه كه يدر مادرم يه روزى نباشن. اونا هستن هستم،

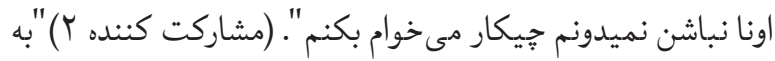
اين فكر مى كنم كه الان شوهرم جوونه، برادرم جوونه، بعدا من يبير

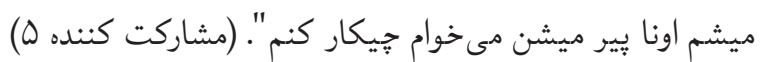
ا V, V. در حسرت سالم زيستن حسرت خوردن براى سلامتى از دست رفته، يكى از تجربههاى تلخى بود كه مشاركت كنندكان در بيانات خود به كرّات به آن اشاره نمودند.

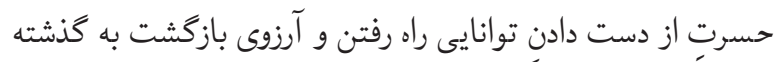

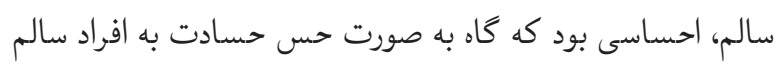

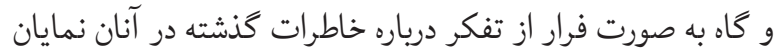
مى شد: "...بعد تصادف حس حسادت به من دست مىداد. وقتى 


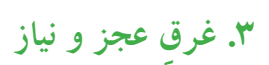

اين مضمون حاكى از عجز و درماندكى مشاركت كنندگان از

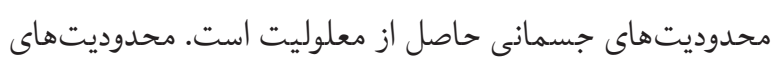

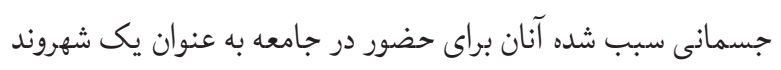
احساس نياز به حمايت از سوى دولت كنند.

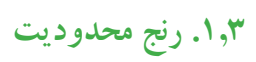

مشكلات جسمانى ناشى از معلوليت، محدوديتهايى را بر زندكى مئى

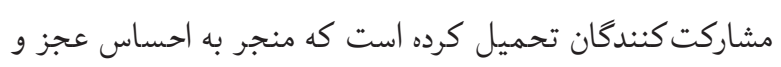
درماندگى در آنان شده است. خانه نشينى و عدم توان انجام كار همجون كذشته، رنج محدوديت را در آنان دوجندان نموده است: " " من قبل تصادف صبح تا شب كار مى كردم زندكيمو مى جرخوندم

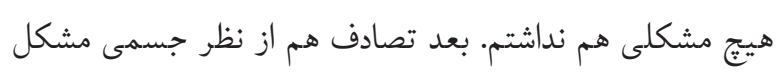

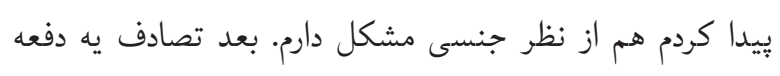

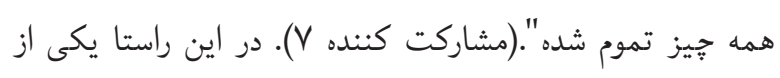

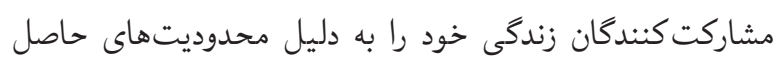

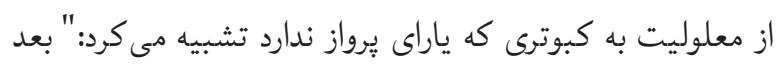
تصادف ديكه نتونستم ورزش برم. فوتبال و تنيس كار مى كردم.

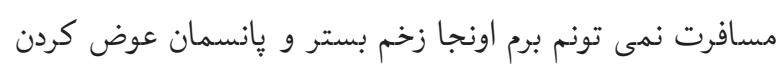

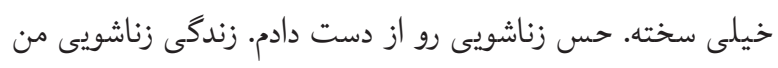
يه حالت مصنوعى شده ديكه. جسممونم كه كلا در عذابه. بدنم درد مى كنه. از بعد از تصادف انغار كبوترى هستم كه ياراى بِرواز

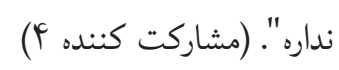
r r r. ب. در جستجوى حمايت اين زيرمضمون نيازِ مشاركت كنندگان به حمايت از سوى دولت

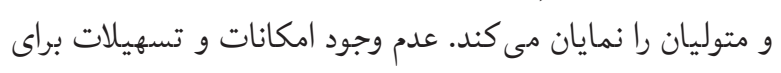
معلولين، حضور آنان در اجتماع را با محدوديت مواجه نموده است. تمامى مشاركت كنندكان از وضعيت نامناسب خيابانها و معابر ابراز ناراحتى مى كردند و معتقد بودند كه مبلمان شهرى متناسب

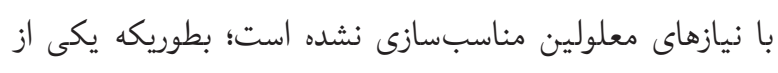
مشاركت كنندكان اختلاف سطحهاى بسيار ناجيز براى افراد سالم را به قلهاى بلند براى معلولين تشبيه مى كرد: "من كل شهرو مرور
قشنكى بود. همه كنارم بودن مهربون بودن اما بعدش همه سه جهار

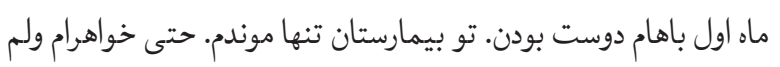

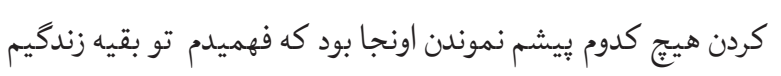

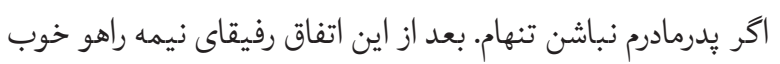
شناختم". (مشاركت كننده Y).درك نشدن از سوى اطرافيان و ناديده

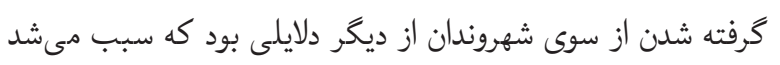
مشاركت كنندگان خود را در محبس تنهايى گرفتار ببينند: "... از آدما

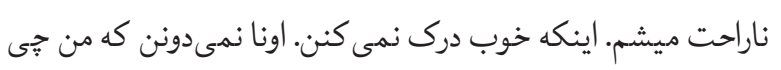

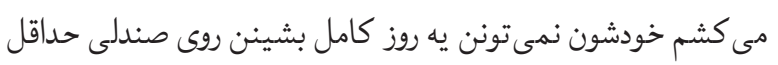

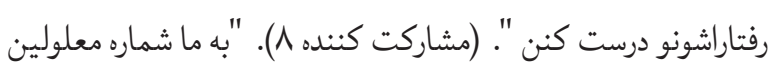

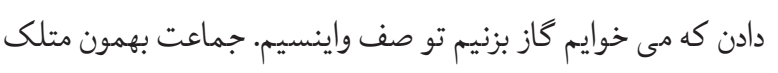

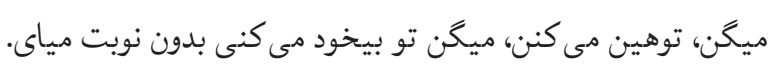

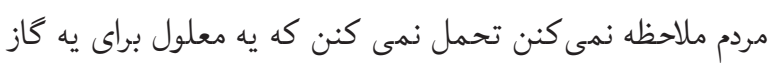

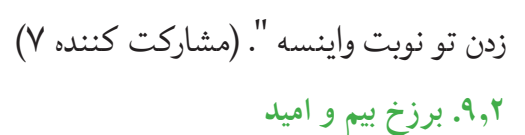

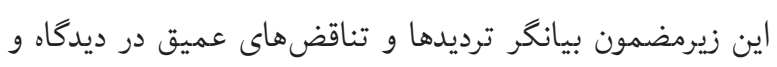

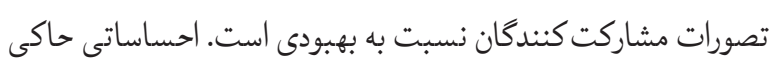

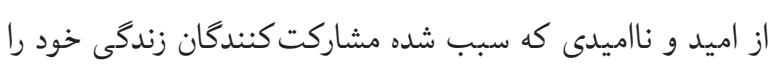

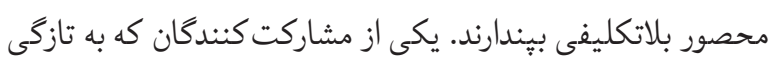

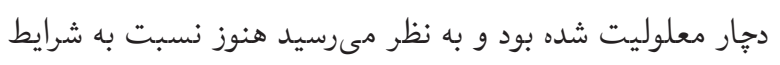

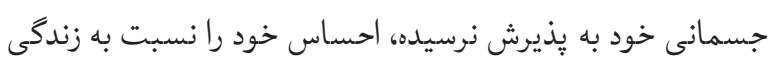

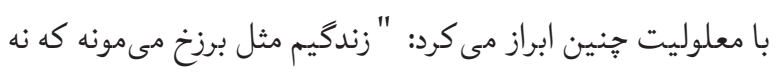

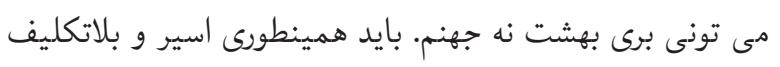

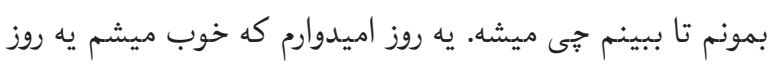

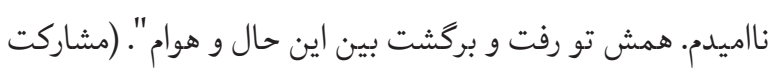

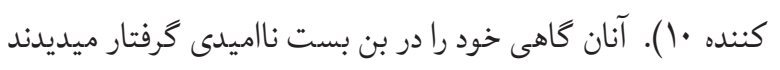
و كاه كورسويى از اميد به بازيابى توان از دست رفته در وجودشان

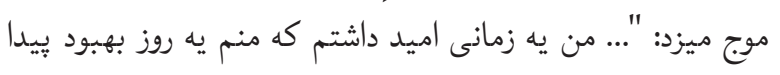

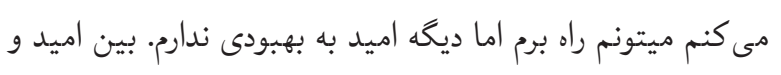

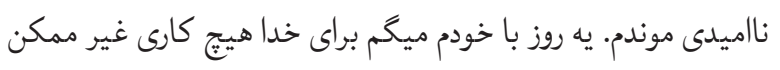

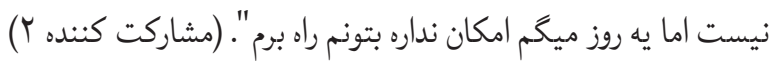


حادث شدن بيمارى از جانب خداوند راهكارى بود كه بيماران براى

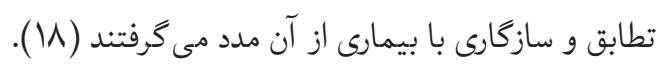
تقدير كرايى و اعتقاد به سرنوشت بد بديدهاي است كه به به واسطه

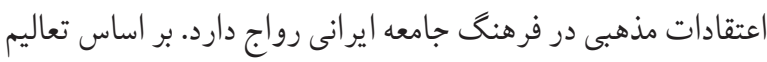
دين اسلام، هيج امرى خارج از اراده الهى تحقق نمى يابد؛ لذا انسان

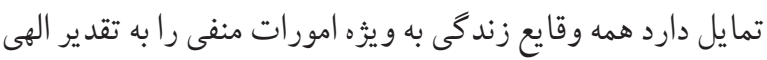

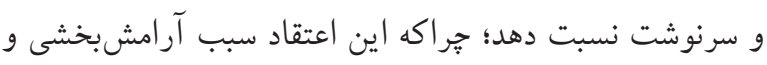

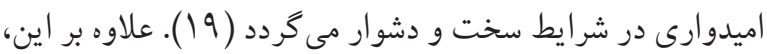

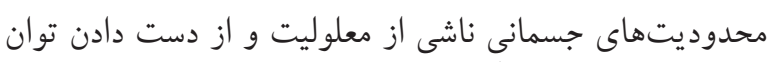

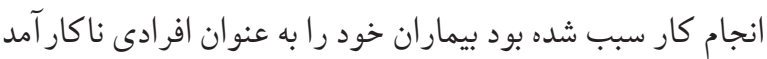

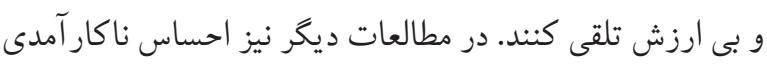
در معلولين جسمى -حر كتى، به دليل از دست دادن شغل و وابستكى اقتصادى به اطرافيان به عنوان تجربهاى ناخوشايند بعد از ضايعه

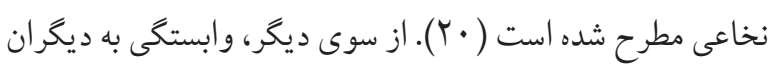

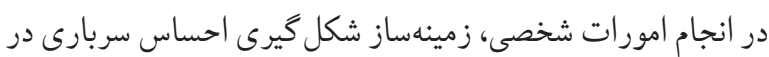

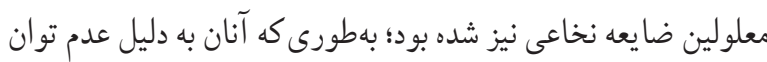
انجام امورات شخصى به صورت مستقل، خود را به عنوان مو جودى ني

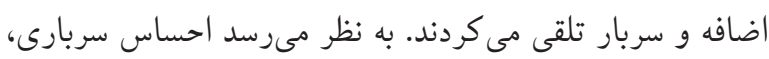
تجربهاى مشتر ك در ميان معلولين جسمى -حر كتى باشد. در مطالعه شر يفى و همكاران، احساس حقارتِ ناشى از سربارى و بىثمرى دري جامعه، تجربهاى بود كه مردان مبتلا به ناتوانى جسمى -حر كتى نيز در تجارب خود به آن اشاره نمودند ( (Y). ناتوانى جسمى -حر كتى به دليل محدوديتهاى عملكردى سبب ميى (بود فرد نسبت به خود تصور منفى داشته باشد (Tr). يكى ديكر از مشكلات تجربه شده از سوى مشاركت كنند كان،

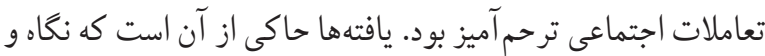

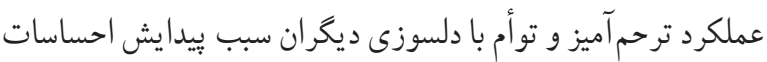
منفى و ناخوشايند نظير احساس حقارت در مشار كت كنندكان شده است. دلسوزىهاى بىموردو كمكهاى ناخواسته و غيرضرورى كه با هدف حمايت و يا همدلى با اين افراد انجام مى كد، در تجرديه مشار كت كنند كان به عنوان ترحم معنى شده است و نه تنها براى إئ فرائ
كردم. يه جايى نيست كه تنها بتونم خودم برم خريد كنم. مناسبسازى

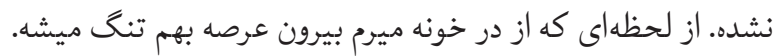

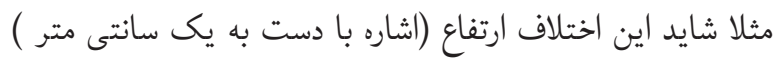

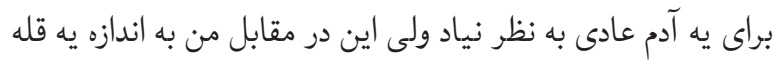

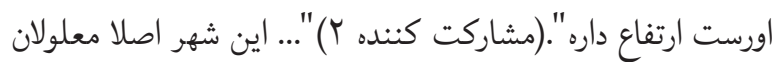
رو به حساب نميارن. نه يِيادرووهامون مناسبه نه ادارهامون مناسبه. هيججا مناسبسازى نشده. تو اين شهر براى معلولان يه امكانات جزئى هم نيست".(مشاركت كننده 9) بحث و نتيجه گيرى يزووهش حاضر به تبيين تجربه زيسته معلولين تصادفات ترافيكى از

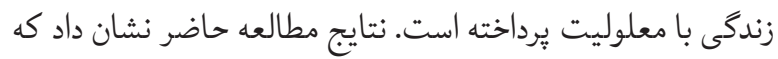
معلولين ضايعه نخاعى، علاوه بر محدوديتهاى فيزيكى (جسمانى)،

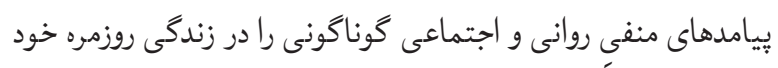

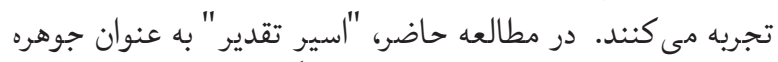
تجارب مشاركت كندكان شناسايي شد. اين مضمون، تصويرى از

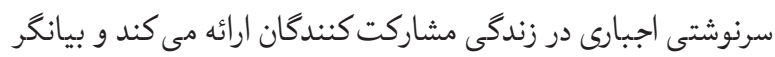

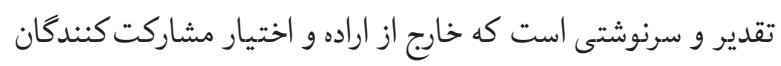

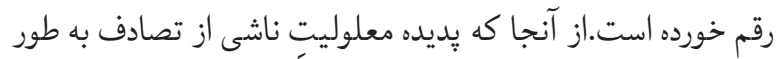

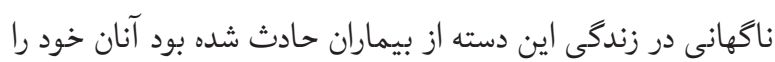

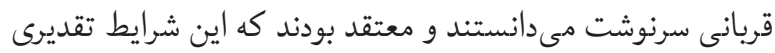

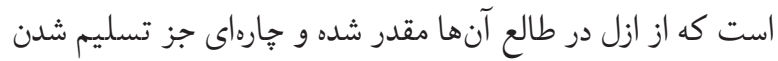
در برابر آن ندارند. برخى از مشاركت كنندكان، معلوليت حادث شار شده

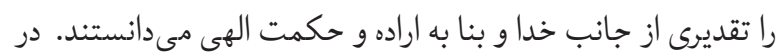
مطالعات قبلى نيز، بر اعتقاد به اراده و حكمت الهى در ميان بيماران

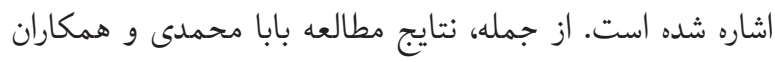

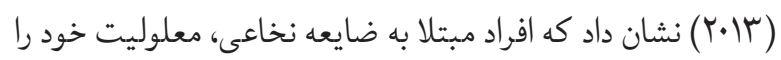

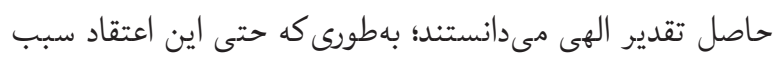

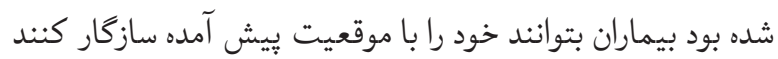

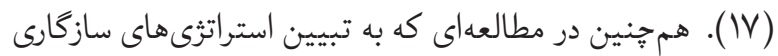
با سرطان پستان در زنان ايرانى يرداخته است، اعتقاد به اراده الهى و 
و حتى مر اقبتهاى روزانه خود به ديكران اتكا مى كنند و بيشتر ين

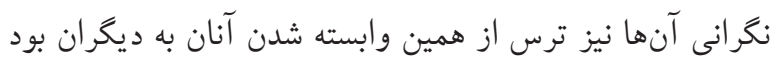
(YF)

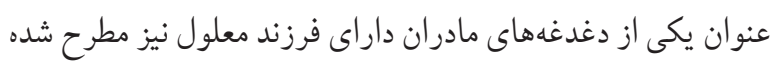

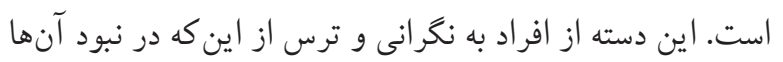

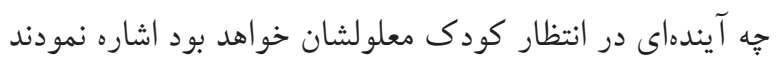

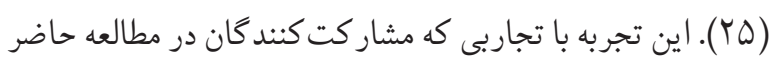

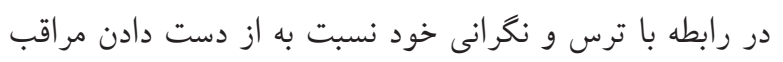

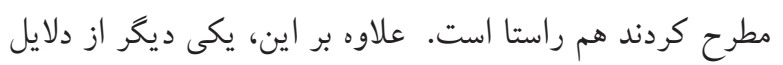

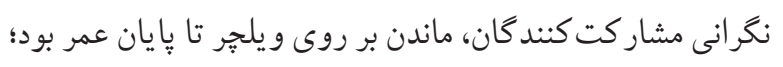

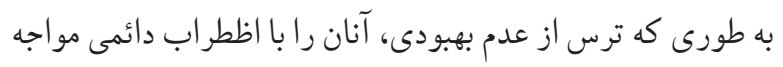

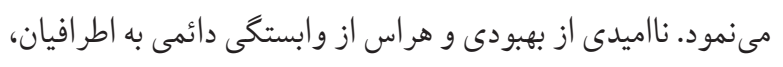

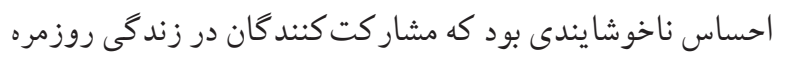

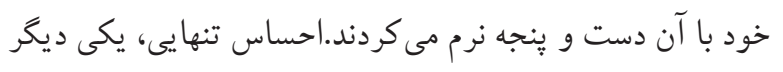

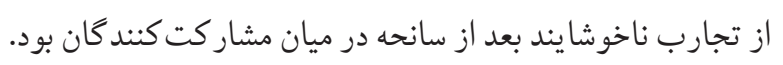

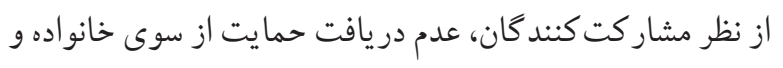
درك نشدن از سوى شهروندان نقش مهمى در بيدايش اين احساس

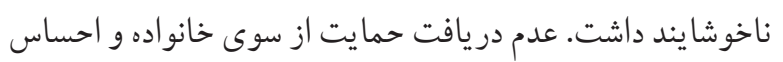

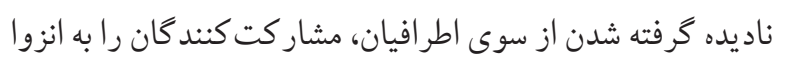
و احساس تنهايى كشانده بود. بسيارى از مشاركت كنند كان ناديده

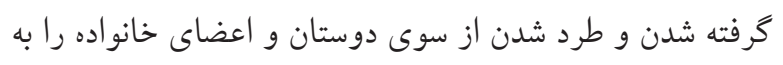

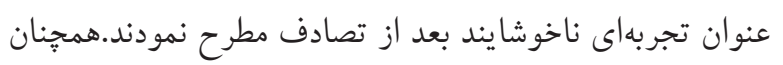

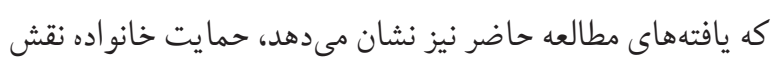
مهمى در بذيرش معلوليت و ساز كارى با موقعيت بيش آمده دارئ دارد.

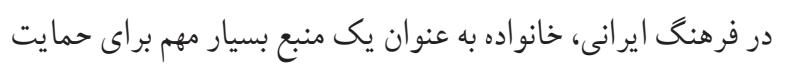

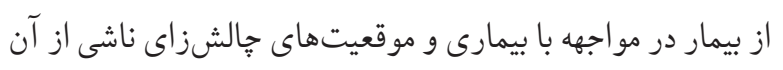
محسوب مىشود (Y) (Y).در يافت حمايت از سوى همسر به عنوان

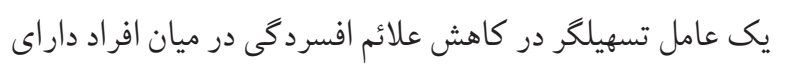

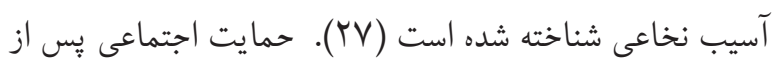

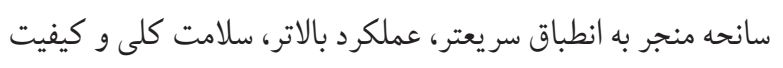

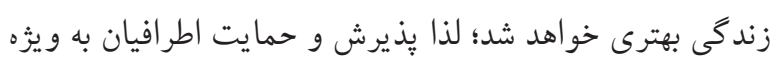

مشاركت كنند كان خوشايند نبود؛ بلكه موجب ناراحتى و رنجش خاطر آنان نيز شده بود. مشار كت كنند كان انتظار داشتند مردم در

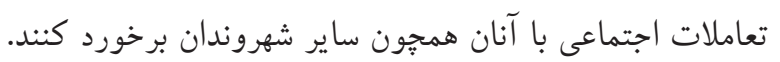
حس ترحم و دلسوزى نابجاى اعضاى جامعه نسبت به معلولين ضايعه نخاعى در ساير مطالعات داخلى و بين المللى كه به تبيين

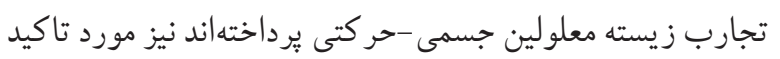

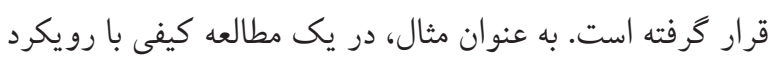

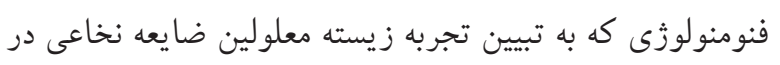

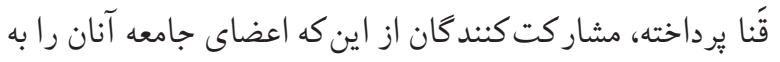

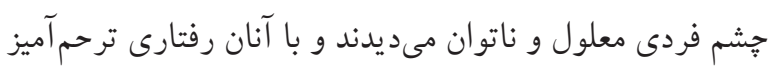
داشتند ابراز ناراحتى كردند (·) (Y). در مطالعه خانجانى و همكاران

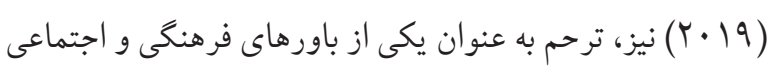

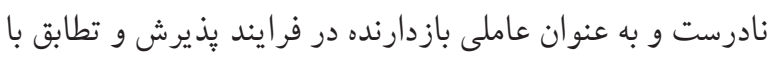
بيمارى مطرح شده است كه براى معلولين ضايعه نخاعى رفتارى بـ بارد

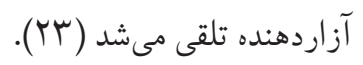
در فرهنگ جامعه ايرانى، ترحم و دلسوزى بر فرودستان و

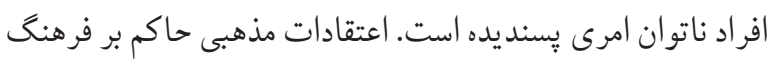

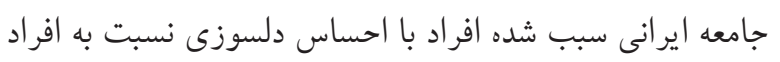

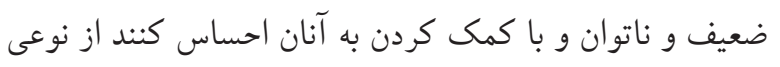
بيمه معنوى برخوردار مىشوند. در واقع آنان معتقدند توجه نشان

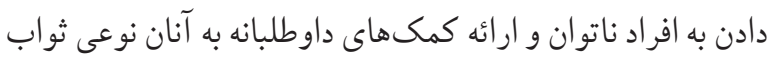

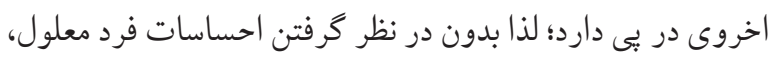

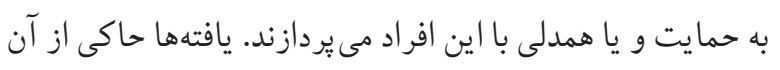

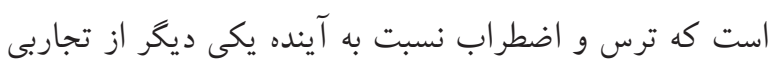

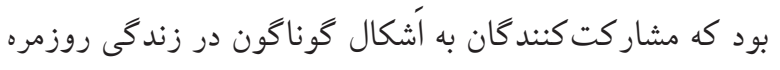
خود با آن دركير بودند. ترس از دست دادن حامى و يارى كرسان

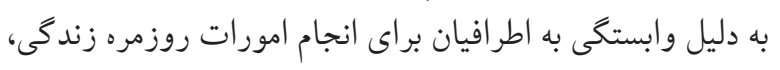

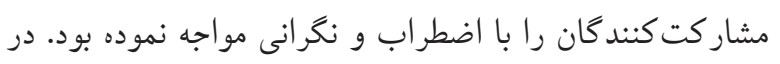
يك مطالعه كيفى، معلولين ضايعه نخاعى به وابستكى به اطرافيان

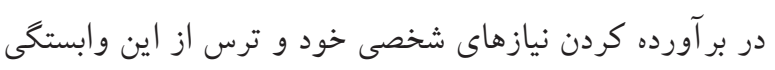

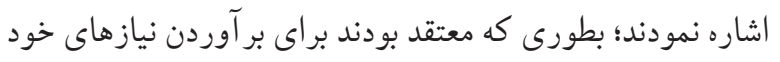


و تغيير نكاه اجتماعى در برخود با افراد معلول در جامعه ضرورى مىنمايد. يافتهاى حاصل از اين يثزوهش، لزوم طر احى و اجراى مداخلات

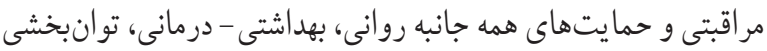

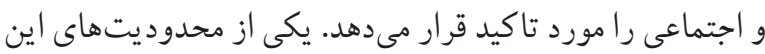
مطالعه، عدم امكان دسترسى به ساير معلولين جسمى - حركتى بود كه به مر اكز توانبخشى و يا ساير مراكز ارائهدهنده خدمات به

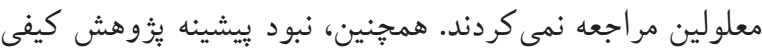

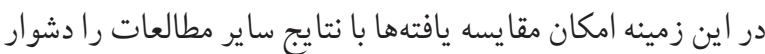
مى نمود. براى دستيابى به درك جامعتر از نيازهاى افراد مبتلا به

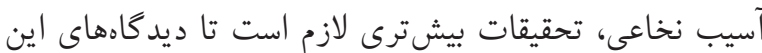

$$
\text { بيماران در زمينهاى فرهنكى متفاوت بررسى شود. }
$$$$
\text { تشكر و قدردانى }
$$

يُزوهش حاضر با مشاركت معلولين ضايعه نخاعى مراجعه كننده به

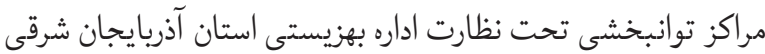
انجام شده است كه از مساعدت و همكارى اين عزيزان صميمانه تشكر و قدردانى مى نمائيم. از حمايت هاى اداره بهزيستى استان

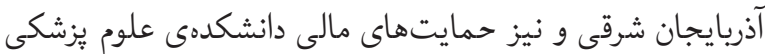

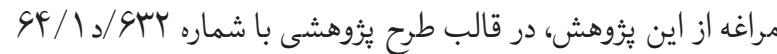
قدردانى مى گردد.

\section{References}

1. Rezaei M, Partovi L. Disable Women and Interaction with Society (a qualitative study on social life of disable women). Womens Strategic Studies. 2015;17(67): 744.

2. Cieza A, Stucki G. The International Classification of Functioning Disability and Health: its development process and content validity. European journal of physical and rehabilitation medicine. 2008;44(3):303-13.

3. Rezapur-Shahkolai F, Ranaei V, Hazavehei MM, Faradmal J. Performance of Police-Assistant Students Compared with the Other Students in Schools of Hamadan, Concerning the Prevention of Road Traffic Injuries. Iranian Journal of Health Education and Health Promotion. 2018;6(2):95-101.. https://doi.org/10.30699/acadpub.ijhehp.6.2.95

4. Abedi $\mathrm{H}$, Ahmadi F. Reflection on the experiences of disabled people: The society as a cause of growth or barrier. Journal of Qualitative Research in Health Sciences. 2013;2(3): 248-
اعضاى خانو اده در سالهاى نخست پِ از تصادف تاثيرات مثبتى بر سلامت جسمى، روحى، روانى و كيفيت زندگى پِّ از ضايعه خواهد داشت (f). در مطالعهاى كه به تبيين تجربه همسران معلولين ضايعه نخاعى يرداخته است، حمايت خانواده و به ويثه اشخاص

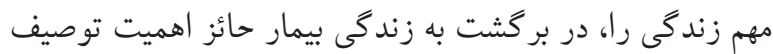

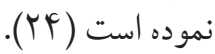
حمايت نشدن از سوى دولت، ناكار آمدى سازمانهاى حمايتكر در ارائه خدمات مناسب به معلولين و نيز عدم وجود مبلمان شهرى متناسب با شر ايط معلو لين از ديكر مشكلاتى بود كه مشار كت كنند كان در تجارب خود به آن اشاره نمودند. جالشهاى مربوط به به ارائه خدمات اجتماعى و بى توجهى به شهر دوستدار معلول در مطالعات ديكر نيز به عنوان يك تجربه مشترى در ميان معلولين جسمى حركتى اشاره شده است (Y^). اين مطالعه نشان داد كه معلوليت،

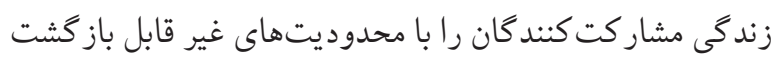
و جبران نايذيرى مواجه ساخته است؛ بهطورى كه آنها به عنوان

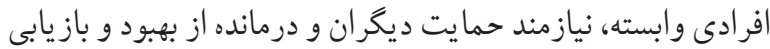
توان از دست رفته، خود را در محبس سرنوشت گرفتار مىدانند؛

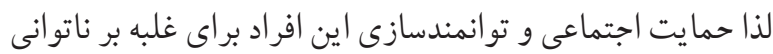

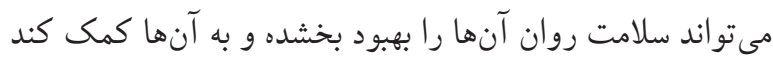
تا به زندگى عادى باز كردند. همجِنين با توجه به تجارب ناخوشايند مشاركت كنند كان در حوزه روابط اجتماعى، لزوم فرهنگسازى

60.

5. Sleet DA, Dahlberg LL, Basavaraju SV, Mercy JA, McGuire LC, Greenspan A. Injury prevention, violence prevention, and trauma care: building the scientific base. MMWR Surveill Summ. 2011;60(Suppl 4):78-85.

6. Hatamabadi HR, Soori H, Vafaee R. Epidemiological pattern of road traffic injuries in Tehran-Abali Axis in 2008: A prospective study. Payesh.2012; 11 (1):29-37.

7. Rezaei M, Partovi L. Disable Women and Interaction with Society (a qualitative study on social life of disable women). Womens Strategic Studies. 2015;17(67): 744.

8. Oliveira L, Macedo A, Buchalla C, Scatena J. Evolution of disability in traffic accident victims in rehabilitation, characterized by the International Classification of Functioning, Disability and Health (ICF). Fisioterapia em Movimento. 2017; 30(2): 267-75. 
https://doi.org/10.1590/1980-5918.030.002.ao07

9. Malm S, Krafft M, Kullgren A, Ydenius A, Tingvall C. Risk of Permanent Medical Impairment (RPMI) in Road Traffic Accidents. Annals of advances in automotive medicine. 2008;52:93-100.

10. Coupland C, Morriss R, Beckett K, Joseph S, Barnes J, Christie N, Sleney J, Kendrick D. The impact of psychological factors on recovery from injury: a multicentre cohort study. Social psychiatry and psychiatric epidemiology. 2017; 52(7): 855-66. https://doi.org/10.1007/s00127-016-1299-z PMid:27803978 PMCid:PMC5504249

11. Nasiripour A, Tabibi J, Afkar A, Kamali M. Effect of community based rehabilitation program implementation on disabled people living conditions in Iran. Journal of Knowledge and Health. 2012; 7(4): 174-8.

12. Pashaei Sabet F, Norouzi Tabrizi K, Khankeh HR, Saadat $S$, Abedi HA, Bastami. Road traffic accident victims' experiences of return to normal life: A qualitative study. Iranian Red Crescent Medical Journal. 2016; 18 (4): e29548. h tt p s : / / d o i.org / 10.5812 /ircm j . 29548 PMid:27275399 PMCid:PMC4893411

13. Palmera-Suárez $R$, López-Cuadrado $T$, Almazán-Isla J, Fernández-Cuenca R, Alcalde-Cabero E, Galán I. Disability related to road traffic crashes among adults in Spain. Gaceta sanitaria. 2015;29: 43-8. https://doi.org/10.1016/j.gaceta.2015.01.009 PMid:26342420

14. SoltaniSH, Takian A, Sari A, Majdzadeh R, Kamali M. Financial Barriers to Access to Health Services for Adult People with Disability in Iran: The Challenges for Universal Health Coverage. Iranian Journal of Public Health. 2019; 48(3): 508. https://doi.org/10.18502/ijph.v48i3.895 PMid:31223579 PMCid:PMC6570792

15. Van Manen M. Professional practice and 'doing phenomenology', in Handbook of phenomenology and medicine. Springer. 2001; 457-74. https://doi.org/10.1007/978-94-010-0536-4_24

16. Guba EG, Lincoln YS. Guidelines and checklist for constructivist (aka fourth generation) evaluation. 2001.

17. Babamohamadi H, Negarandeh R, Dehghan-Nnayeri N.Important coping strategies used by individuals with spinal cord injury: A qualitative study. Journal of Qualitative Research in Health Sciences; 2013: 2(1): 90-100.

18. Taleghani F, Yekta ZP, Nasrabadi AN. Coping with breast cancer in newly diagnosed Iranian women. Journal of Advanced nursing. 2006; 54(3): 265-72. https://doi.org/10.1111/j.1365-2648.2006.03808_1.x PMid:16629910

19. Karami MH. Destiny in Persian literature and its impact on the culture of the Iranian people. Journal of the Faculty of Literature and Humanities.2004;54 (1):129-50.
20. Fuseini A, Aniteye $P$, Alhassan A. Beyond the Diagnosis: Lived Experiences of Persons with Spinal Cord Injury in a Selected Town in Ghana. Neurology research international. 2019;3: 1-10. https:// doi .org/10.1155/2019/9695740 PMid:30792925 PMCid:PMC6354163

21. Ardani AS, Tazerjan SA, Fattahi G. Explaining the Lived Experience of Men with Physical-Motor Injury in Marriage: A Phenomenological Approach. The Journal of Tolooebehdasht. 2019; 17 (6): 46-60.

22. Sofiani L, Bafandeh Gharamaleki H, Ezati M. A Comparative Study of Theory of Mind and Body Image between People with Motor Disabilities and Normal people. Middle Eastern Journal of Disability Studies. 2017;7:65. https://doi.org/10.4324/9781315399423-5

23. Khanjani M, Khanekeh $H$, Younesi $S$, Azkhosh M. The Main Factors Affecting the Acceptance and Adaptation With Spinal Cord Injury: A Qualitative Study. Archives of Rehabilitation. 2019;19(4):276-91. https://doi.org/10.32598/rj.19.4.276

24. Nikbakht A, Gomarverdi S, Bastami A, pashaii sabeti F, Bastami M, Sabaghieh Yaz MR. Spouses' experiences of living with patients with spinal cord injuries: a phenomenological study. Iranian Journal of Nursing Research. 2017;12(3):24-35. https://doi.org/10.21859/ijnr-12034

25. Khodabakhshi-Koolaee A, Koshki MA, Kalhor N. Analysis the experiences of mothers in caring of a disabled child: A phenomenological Study. Journal of Pediatric Nursing. 2019;6(2):68-75

26. Allahbakhshian A, Hasankhani H, Mohammadi E, Zamanzadeh V, Allahbakhshian M. Coping strategies used by patients after coronary angioplasty: a qualitative study. Iranian Journal of Nursing Research. 2015;10(1):42-55.

27. Kalpakjian CZ, Houlihan B, Meade MA, Karana-Zebari D, Heinemann AW, Dijkers MP, Wierbicky J, Charlifue S. Marital status, marital transitions, well-being, and spinal cord

injury: an examination of the effects of sex and time. Archives of physical medicine and rehabilitation. 2011;92(3):433-40. https://doi.org/10.1016/j.apmr.2010.07.239 PMid:21276959 PMCid:PMC3594832

28 - Kumar SG, Roy G, Kar SS. Disability and rehabilitation services in India: Issues and challenges. Journal of Family Medicine and Primary Care. 2012;1(1):69. https://doi.org/10.4103/2249-4863.94458 PMid:24479007 PMCid:PMC3893941 